\title{
И. М. Меликов
}

\section{Педагогический аспект гуманитарных наук}

В центре внимания автора - вопрос о значении преподавания гуманитарных наук в высших учебных заведениях. В качестве цели преподавания гуманитарных наук часто рассматривается просто расширение мировоззрения студентов. Но на самом деле оно играет еще и важную роль в процессе формирования профессиональных качеств. Исследование проводилось на основе диалектического и системного методов.

Основные результаты исследования сводятся к идее о том, что гуманитарные дисциплины в высших учебных заведениях выполняют три чрезвычайно важные функции: во-первых, дают основание для целостного восприятия знаний и их понимания; во-вторых, развивают творческие способности студента; в-третьих, развивают его личностные качества.

Новизна и значимость результатов заключается в выводе о том, что без творческих и личностных характеристик ни один человек, несмотря даже на подготовленность в профессиональной области, не может быть полноценным специалистом. Они составляют основу профессиональных качеств любого специалиста. Только на их основе человек становится профессионалом. Иначе он становится однобоким и одномерным, в результате чего его чисто профессиональные навыки становятся ущербными. И в этом плане ценность гуманитарных дисциплин более значима, чем даже профессиональная подготовка. В этом заключается их непосредственная практическая польза.

Ключевые слова: гуманитарные науки, гуманизация образования, образование, внутренний мир, понимание, творчество, личность, свобода, высшая школа, профессионализм

\section{Ссылка для цитирования:}

Меликов И. М. Педагогический аспект гуманитарных наук // Перспективы науки и образования. 2020. № 2 (44). С. 30-46. doi: 10.32744/pse.2020.2.3 


\section{M. MeLiKOV}

\section{Pedagogical aspect of humanities}

The author focuses on the matter of reason of teaching humanities in higher education establishments. The goal of teaching the human sciences is often being esteemed simply to expand the students' worldview. But in fact, it also plays an important role in the process of forming professional qualities. The research pursued based on dialectical and systemic approaches.

The main results of the study appear to the idea that humanitarian subjects in higher education establishments fulfill three extremely important functions: first, they provide the basis for a holistic perception of knowledge and their deep understanding; secondly, they develop the student's creative abilities; thirdly, they develop his personal qualities.

The newness and significance of the results lies in the conclusion that, without creative and personal characteristics, not a single person, even despite preparedness in the professional field can be a full-featured specialist. They form the basis of the professional qualities of any specialist, and only in terms of them, a person becomes a professional. Otherwise, he becomes one-sided and one-dimensional, because of which his purely professional skills become flawed. Moreover, in this regard, the value of humanitarian subjects is more significant than even professional training. This shows their proximate practical usefulness.

Key words: humanities, humanization of education, education, inner world, understanding, creativity, personality, freedom, higher school, professionalism

\section{For Reference:}

Melikov, I. M. (2020). Pedagogical aspect of humanities. Perspektivy nauki i obrazovania Perspectives of Science and Education, 44 (2), 30-46. doi: 10.32744/pse.2020.2.3 


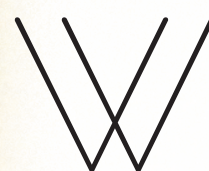

hat does a young specialist who has graduated from a higher educational establishment should look like today? In the best case, he must learn a certain system of knowledge as well as to become a person filled with knowledge and able to work in accordance with them. Indeed, knowledge provides a lot in the learning process. Students are literally overloaded with knowledge. There is too much of it, so that it is impossible to keep in mind. Therefore, they are often forgotten, thrown into the "attic» as something unnecessary.

The current education system in higher education is being built similarly to the process of programming robots, as if students are not human beings, but robots in which need to be filled with knowledge system. Then, is it not better to product robots instead of higher education establishments? It is more than obvious that it will be cheaper and more economical. You can put much more knowledge and information into the robot than into the head of a future specialist; he has excellent memory in comparison to human beings, never forgets anything, and indeed works better than humans do. Nevertheless, probably, we need, first, not robots, but specialists.

However, could we say that the student who has mastered the entire amount of knowledge is already a specialist? Too obvious that he is not. Why? The fact is that the process of specialist formation cannot be reduced only to the assimilation of knowledge. In addition, as the ancient Greek philosopher Heraclitus put it, multi-knowledge does not teach the mind. A specialist must have, for sure, a certain system of knowledge. They are necessary. However, a specialist must have a much wider range of qualities and competencies.

Today, the development of the modern world requires its qualitative transformation of the system of public relations. Accordingly, this is possible and real through changing the type of specialist. Therefore, the educational process in higher education should involve a change in the approaches to scientific and technical activities themselves, a new "paradigm" of activity. It should be aimed at the future development of science, technology and the entire production process. As O. B. Ivanov and S. V. Ivanova write, «designing an educational space should be considered as a managerial, not a methodological problem» $[1$, p. 46]

The technocratic approach, in which the human essence of man is ignored and being lost, in which he turns into a simple object of technology, into an appendage of the machine, into the "human factor", must be overcome. Technocratism is contrary to humanism. In this regard, the teaching of the humanities plays one of the most crucial roles in the process of humanizing human relations and human activity, in the process of eliminating all technocratic trends in social processes.

In the modern world, it is believed that only by being based on a utilitarian and pragmatic approach, adequate development of science and production is possible. In particular, in contemporary philosophy of education, pedagogy and social-pedagogical management model, the technocratic approach to education management, in the form of methods of behavior modification for the implementation of the adaptation of the individual to the social, economic and political system, developing the concepts of neobehaviorism (E. Maurice M. Black and others) [2, p. 352-370]. That is primarily based on the ideas of psychology of the behaviorism of B. Skinner. 
Proponents of this trend reject self-development of the individual as the main goal of education, seeing this as one of the main causes of social and moral crisis. They proceed from the premise that a person is a trainable-modifiable being, and it is in the process of training that all the norms of his behavior are developed. In order to achieve the goal of power, management, and education, which is sometimes reduced by neobehaviorism to manipulating people, resorted to appropriate methods, in which various forms of training and behavior modifications based on reinforcement factors appear.

But the fact is that if a business is built on a utilitarian basis, it is doomed to collapse, since a utilitarian and mercantile approach prevents a person from achieving the goal. As they say, a miser pays twice. Oddly enough, the utilitarian approach is not pragmatic and unprofitable. It is not about a profitability of a profit, but what is above it - spirituality and morality. There is nothing profitable than morality, as it is invisibly embodies the highest practice, the highest law, the highest benefit. What is moral is always profitable. Welcome absolutely. Therefore, moral imperatives should be above all in any kind of activity, because only what is based on morality can bring good and good to people.

Nowadays, a deficiency of morality is observed literally in all spheres of human activity. However, unobservable moral laws hit the man himself, and even turn against himself. No matter how much knowledge we possess, they cannot replace morality for us. The consequence of which are the global problems of our time and other troubles of a humankind? Lack of knowledge? Not. Failure to comply with the elementary requirements of morality. Therefore, a new type of professional involves not only a knowledgeable, understanding creative individuality, but also a spiritual, moral individuality.

What makes a person a specialist in a particular business? After all, a specialist is a person who has not just learned a certain amount of knowledge, but owns it, knows how to apply this knowledge, and even develop his own in accordance with the experience of his activity. Therefore, the status of a specialist implies an appropriate level of creative abilities. Therefore, the learning process in higher education involves not only the assimilation of knowledge, but also equally - the development of creative abilities. Do special and specialized disciplines provide the development of creative abilities? Yes, only to a certain level. To the level achieved by these sciences. A higher level of development of creative abilities is no longer in special fields. It is associated with universal abilities.

Oddly enough, the training of a creative specialist, professional is only one side of the matter. Another, no less important, is the formation of his personal qualities. We are rightly indignant when a mediocre boss, a heartless doctor, or a rude person occupies an important post, when a person meets only formal requirements, and in fact is not substantial. However, can there be a good doctor who treats his patients poorly? After all, the doctor treats not only with medicines, but also with his attitude. Can a good professional be culturally undeveloped? A good specialist firstly is an extraordinary person. It is only a developed person who could become a good specialist.

Any specialist consists of two components: the person himself and what is called a specialist. In higher education, emphasis is placed on the second thing. Nevertheless and most likely - more, significantly the first, related to the preparation of the human component of the specialist. Any specialist is first and foremost a person, so if the major subjects disciplines form purely professional qualities in a student, then humanitarian ones are purely human. For a person to take place as a specialist, an appropriate human, personal potential is being needed. Humanitarian subjects are called upon to develop this potential. 
The study was conducted on the basis of dialectical and systemic methods. The dialectical approach allowed us to consider the educational process as a unity of its opposite sides. Based on a systematic approach, a connection was created between the teaching of professional and humanitarian disciplines, the role of the latter in the educational process was determined. The combination of methods characteristic of socio-philosophical research was valuable: historicism, historical-cultural, comparative-historical, analogies and deductions.

Results

\section{Humanities and the inner world of a human}

The humanities differ from the natural and technical in that they are sciences that are primarily associated with man. The word "humanitarian" literally means "human." But a human being is studied by anatomy, physiology, and other sciences, which cannot be classified as humanities. So, to say that the humanities are connected with a person is not enough, and this does not yet reflect their essence. The fact is that the humanities are connected not just with a person, but with his inner world, with his soul and spirit. The basis of all the humanities is precisely the spiritual, psychological factor. The human psyche in them is the main thing, it is the basis (Lotman, Yu.M) [3]. All the rest is a manifestation of the psyche, it is secondary to the psyche. Whatever is said about them, about historical events or about art, religion or morality, the human soul remains in the main place. Moreover, the human body may also be interested in the human body itself, say, in fine art or culture, but this will not be the body that is considered in anatomy. This body is not an organism, it is corporeality, a reflection of the soul.

In all natural, especially technical sciences, - first of all, reason and logic. These are purely rational formations. Soul as such is not in them. There is only reason. Therefore, they are theoretical and built on strict logic. In the humanities - primarily the spirit and soul of man. Irrationality in them is the basis. Rational, the mind in them is only an expression of irrational experience. All of them are built on psychological experience, and not on logic. The humanities are rather illogical than logical. All reasoning in the humanities is based more on pure intuition than on logic. They are more like a set of illogical, even contradictory judgments, than a rigorous theory.

Actually, the very use of the word "science» in relation to them is very arbitrary. If a theory is present in them, which is, as you know, a characteristic feature of science, then it is too fragile and fragile and, as a rule, easily falls apart. For excessive theoretical, strict logic in them is tantamount to death. Theory and logic are too limited to express a person's emotional experience. Therefore, their absolutization could lead to a transformation into a variety of natural sciences.

As soon as the logic in them begins to take over the experiences, immediately they lose their "humanitarian». Reason is something in common between people. The soul is individual, and the spirit of man is personal. While people can have the same thoughts, everyone's emotional experiences are individual and unique. Therefore, in the natural sciences, man as such is not present. There is no authorship in them, so they are impersonal. 
Invented one or another formula Faraday or Newton for physics itself does not matter. The formula itself has significance for it. Physics is not interested in Faraday or Newton as a person, as a unique individuality and personality.

All natural sciences are impersonal, even when a particular theory is called the name of the scientist who discovered it. This is just a name and nothing more. All natural and technical sciences are abstract, the humanities are concrete, for the basis of the natural and technical sciences is abstraction, and the humanities are concrete reality. Natural and technical sciences abstract from man, from his spiritual and material reality and thereby break away from himself. They do not have anything that affects the soul of man. They are interesting only to the theoretical mind of man.

The humanities come from human being. They are always present either a real earthly person, or a spiritualized person, personality. And everything that fits into the framework of the humanities reflects the real life experience of people. In the framework of the natural sciences, we are dealing mainly with the experience of the mind. The natural and technical sciences are built on rationality, on the human mind, and the humanities on spirituality.

The natural and technical sciences absolutize the human mind, the humanities come from its limitations. Therefore, the humanities cannot be built on formal logical principles. Each of them selects its own adequate way of expression. The form of expression in each case in the humanities is always its own, it is different each time from others, so it is diverse. However, the content in them is the same. In other words, the whole variety of forms of expression, the seeming disorder of reasoning in the humanities is a reflection of deep unity. All of them are characterized by substantial unity in the Logos and a variety of forms of expression. And the mess of thoughts in them is just a mess for the limited human mind. In fact, the disorder in the humanities really only seems to exist; there is a deep and thorough order in them. But this order, unlike the human understanding of the order, has an informal, but essential nature.

From this follows the artistry and imagery of humanitarian thinking. No wonder A. Camus said: "If you want to be a philosopher, write novels." Thus, he contrasted conceptual and theoretical philosophy with a non-conceptual, figurative philosophy, which is more in line with the idea of wisdom [4].

The humanities are personal. They are built on the individuality of a person, on the basis of his psychological type. It is ridiculous even to assume that Berdyaev could become a rationalist and follower of Hegel. Or that Seneca would call in his works for a revolutionary reorganization of the outside world. Each weighty word in them is unique and inimitable. And it is not reducible to general theoretical reasoning. From the works of humanities scholars, one can always determine their character and psychological type. In Berdyaev's works - he is all by himself, in Hegel's works - his way of life, Freud - his spiritual world, Karamzin - his personal experience of history. However, in the mechanics of Newton, Newton himself is not, in the theory of Darwin, there is no Darwin.

All natural sciences are sciences about the external world of man. The humanities are sciences about the inner world of man. The former are rational, the latter irrational. The former are built on consciousness and reason; the second on feelings, emotions and soul. This is what unites them with art. Therefore, at their core, they are more an art than a science. A historian H.L. Borges generally called a prophet foretelling the past.

A noteworthy example is with N. Berdyaev. He is often being blamed for the fact that in his works there is no clear logic that he writes in circles, often repeating himself and sometimes returning to what has already been said. However, these reproaches would 
be substantiated if Berdyaev were a scientist - a representative of the natural sciences. However, they are inappropriate in relation to the humanities scientist. We can say that the style of Berdyaev is similar to the style of music, song or poetry, where movements in a circle, repetitions and a return to already completed are also observed. It is no coincidence that neither in music nor in poetry it is not accepted to criticize in general.

But why do we need such tricks? The fact is that through repetition, through walking in a circle, the author helps others to penetrate into his world, as if generates forces that allow him to delve into his experiences and evoke others like him. In addition, this is not just a repetition, but really a deeper insight into the issue at hand. Having said something, Berdyaev returns to this at a different turn and considers the problem from a different perspective and in a different way. And any work of the humanitarian sphere can claim to be true, maybe not because of its logic and harmony, but because of how much it causes empathy, what is its power of influence.

The humanities are based on poetry, a poetic perception of the world, in contrast to the rational-scientific. And therefore, we can say that if all natural sciences are as much sciences as they are likened to mathematics, then all humanities are as sciences as they are likened to poetry and music.

The humanities are sciences about the inner world of man. Moreover, even those who explore the external world of man. Their basis is always the inner world of man, despite the fact that they are dealing with the outside world. For example, take historical science, which examines the external events of the past. However, it should be remembered that historical science is built on memory, and memory is the heritage of the inner world. The humanities do not develop external reality, but namely the inner world of man. The basis of the humanities is creativity- it is informal and personal.

However, the inner world can be spiritual and unspiritual. Proceeding from this, the humanities can develop both the spiritualized inner world of man and the inner world of the spiritless. Therefore, although the only, but very serious and deep problem of the humanities is the lack of spiritual factors and the spiritual aspiration of the inner world. Often in them there are no ideas at all, but exist as one experience and feeling. Therefore, the humanities are not always spiritualized, they do not always embody spiritual ideals, they do not always imply moral imperatives, they do not always reveal the question of what should be, how it should be.

\section{The role of the humanities in understanding}

In our era, we prefer knowledge over understanding, which is what Kulikova T. V. pays attention to [5]. It is important for us to know more than to understand. However, knowledge, whatever it may be, cannot give us truth. Knowledge is only a form in which truth is clothed, and not truth itself. Truth is beyond knowledge, knowledge cannot cover it, and it is only transmitted through them, as V. A. Lektorskij notes [6]. The truth itself is not in knowledge, but in understanding.

Knowledge is rational, formal, and truth, reality, being are irrational. Knowledge is always the result of a certain formalization and rationalization. Understanding, however, involves going beyond these forms of conventions, implanting a subject into an object, into reality and experiencing truth. By assimilating knowledge, the student is opposed to the object. The object of knowledge is alien to the student (Pashkova N.V.) [7]. When understanding is reached, the opposition between the subject and the object disappears, and the object becomes understandable, close, "native» to the student. A living person 
is a person who, unlike a robot, is capable of understanding, not just remembering, emphasizes Sidorova G. M. [8].

The meaning of teaching the humanities lies precisely in the "humanization" of the educational process, in its humanization. The teaching of the humanities in higher education does not at all boil down, as it sometimes seems, to simply diversify education, to give some information about the humanities. The teaching of the humanities provides for such a system of education that involves in a student not the mechanical qualities of a robot, but primarily the qualities of a living person, with its undoubted advantage not only to know and remember, but also to understand and experience [9].

However, where does the humanities come in? The point is precisely that it is precisely the humanitarian disciplines that are called upon to reveal in the student the abilities of understanding, the ability to live in and experience. It is humanitarian disciplines, the feature of which is the presence of not only knowledge, but also the need for their deep understanding, deep experience. The student, mastering the humanitarian culture, becomes able not only to remember knowledge and formulas and use them mechanically, but first of all to understand them. Due to the development of the experience of experience gained from the humanitarian sphere, he has a voluminous vision of particular scientific and general scientific issues. He becomes able to acquire knowledge not at the level of trifles, not at the level of knowledge, fragmented into the smallest parts, as a result of which all integrity of knowledge is lost, but at the level of methodology. Experience and allows you to maintain the integrity of knowledge, their integrity, which was mentioned by the Russian philosopher V.S. Soloviev, criticizing the «abstract principles» of the positivists [10]. The unity of experience and knowledge promotes deep understanding, as a result of which the student is not forced to simply memorize, cram, but he can develop this knowledge. And the knowledge itself does not lie dead weight, but is used and is in constant motion.

The main thing in education is the development of understanding. An educated person is different in that he acts on the basis of understanding. And in order to act without understanding, there is no need to study at a higher educational institution. For sure, philosophy should take a special place among the humanitarian cycle: as the main discipline that develops a culture of thinking and gives a universal experience of experiencing thoughts. As a discipline that does not provide a ready-made system of knowledge, but involves their development on the basis of experience of experience; as a discipline that should abandon the idea of forming a scientific worldview (this is not the task of philosophy) and proclaim as its principle the development of a philosophical worldview [11].

Humanitarian disciplines are called upon to play a decisive role in the transition from the training of a specialist worker to the training of a specialist creator, a person who, after graduating from high school, will not only work, but also be creative in his work.

\section{Humanities and creativity}

The development of universal creative abilities is the matter of humanitarian disciplines due to the fact that humanitarian disciplines are those disciplines that are not connected with objects, not with production, but directly with the person himself. Therefore, they are called humanitarian, i.e. "Human". Humanitarian disciplines are not only "knowledge" disciplines, which are purely scientific disciplines. They, as the necessary side, also presuppose a certain experience of experience, an inner spiritual immersion in the subject of study, the experience of "living" in it. If a particular culture or worldview is considered in the humanitarian discipline, then this cannot be carried out indifferently, without involving personal moments of those 
who are engaged in this, as, say, this happens when they solve a mathematical problem and think about obtaining new chemical material. Humanitarian disciplines are directly related to human life. And life cannot be encompassed either by reason, or by science, or by the most profound theory. Life is unreasonable, but superintelligent. Life is beyond logic and reason. She defies them. Therefore, it can be comprehended only through itself, i.e. through life and experience.

Humanitarian disciplines cannot be perceived on an external indifferent level. They can either be perceived or not. However, their perception involves not only the work of the mind, but also the soul and spirit. They are aimed at revealing the spirit. Therefore, humanitarian disciplines encourage students to develop holistically, revealing and developing existing creative potential in them.

Why is it impossible to train a specialist in a specialized field without humanitarian disciplines? The fact is that all disciplines, with the exception of the humanities, are technical, natural, and all others are abstract, there is no person in them. All words about introducing a human problem into them are meaningless, because this contradicts their essence. Their essence is divorced from man. They are aimed at peace, at changing the world. They are practical, not in the sense of the opposite of theory, but in the sense that they are directed, aimed at practice, and not at cognition and not at comprehension of essence.

In this regard, the concept of the Baden school of neo-Kantianism (V. Windelband, G. Rickert) is noteworthy, whose representatives raise the question of the truth of knowledge [12]. According to them, the Foundation of the truth of knowledge cannot lie in itself. It involves reaching out to something transcendent. The Baden people claim that the world of values is the transcendent basis of knowledge and all spiritual activity of man.

The Baden people claim that the world consists of two spheres: reality and values. Values are invalid, they don't exist. They have no being. However, values have for us the meaning of absolute norms that govern our will, thinking, and aesthetic feelings. If we recognize truth, goodness, and beauty, we recognize logical, ethical, and aesthetic values. Values are higher than reality and reality is subordinate to them. Values form a special world, and evaluating reality forms a special kind of activity that expresses a certain aspect of the spiritual development of the world by man.

Evaluating activity is as important as cognitive activity. Values have the distinctive feature that they cover the entire area of due. Cognition and evaluation Express two different approaches to reality and complement each other. If the knowledge claims that is, the evaluation argues that it should be. Value is what we should strive for, what we should do, and what we value.

According to the neo-Kantians of the Baden school, the Sciences of nature are the domain of the rule of General laws, that is, of necessity. Culture is an area where a person is guided by a free choice of values. Values for a person act as norms, so without them there is no human activity and no culture. The world of values is the world of duty. All culture is possible thanks to values. When embodied in reality, values create cultural goods. Cultural goods are valid in contrast to values that do not have reality.

Humanitarian disciplines differ in that they are aimed at truth, at cognition. In the humanities, everything is for the sake of knowledge, comprehension of the truth. A change in practice is here in the background, and then provided that this plan is available. It cannot be said that the natural and technical sciences do not know, do not reveal the truth. But in them the truth is for the sake of practice. They are applied in nature. All technical and natural sciences are pragmatic, the benefits and benefits in them are above all. In them, 
important is not just truth as in the humanities, but the side of truth that can be put at the service of practice is important. By virtue of this, the truth in them appears not in a concrete, but in an abstract form. Any truth in the natural and technical sciences is abstract. It is divorced from the real conditions of reality. For example, we can cite the law of free fall, which does not consider the fall of any real object. Abstracting from them, he equalizes them all: according to him, both a goose feather and a piece of lead fall the same way. By virtue of this, the law itself becomes abstract, and therefore everything connected with it acquires an abstract character.

In the humanities, truth in a concrete form, its discovery and comprehension, is important. The humanities reveal the truth in full, they, as it were, ascertain the existence of man in all planes, without narrowing down the perspective of the vision, without abstracting from one and not absolutizing the other. The man in them appears in a holistic existence. Exploring the era, the historian does not think about what benefit or benefit from this. He simply explores, not highlighting one thing and not neglecting the other. Therefore, the truth in them is concrete. Therefore, the truth is in man himself. Therefore, there is a person. Therefore, humanitarian disciplines humanize, develop universal human creativity.

Presenting an abstract truth while preparing a specialist who divides benefits from a person, it is always necessary to compensate for it with concrete truth, as if compensating for the lack of abstractness of special disciplines. After all, a student remains a man, no matter how much he becomes a specialist; he needs some universality for adequate development. Otherwise, he turns into a robot, into an obedient performer, devoid of creativity. It is no coincidence that students who are well involved in special disciplines are also well involved in humanitarian disciplines and vice versa.

This idea started to be implemented in the Western education system, which has an applied character. This was prompted by the practice itself. According to observations, those students who attend humanitarian courses become more creative specialists than those who do not listen to them. Therefore only because of this, along with majors in higher education, they began to pay serious attention to purely humanitarian courses.

One of the few researchers of the XX century who paid close attention to the problems of integration in the philosophy of education systems, management, and psychology of education in Economics, society, and pedagogy, was J. p. Dewey is a classifier of the concept of pragmatism, who created its instrumentalist version [13]. His psychological, philosophical, managerial and pedagogical-ethical doctrines have become the methodological basis of a very influential direction in pedagogical and production management. The philosophy of education, reaching the level of the sphere of state and social management. The philosophy of education and pedagogy of pragmatism seek to create a universal ethical system that would serve each person, regardless of their social status, to achieve their individual goal in relation to a particular situation, their personal vision of the good, justice, and equality. The writings of William James, John Dewey, and other representatives of pragmatism are full of value analysis and, in particular, justify a clear moral position.

Further development of this direction is associated with adherents of the neopragmatist concept of pedagogy, the philosophy of education management, which strengthen the individualistic orientation of Dewey's ideas, bringing together the concept of pragmatism with existentialism in many issues. According to neopragmatism, one of the main tasks of higher and secondary educational institutions is to pay more attention to the unique experience of students, to the formation of their individuality, using all the disciplines of the curriculum as far as possible in the learning process. Education and educational institutions 
should serve as a laboratory for discovering the unique «l» of each student, because only then will he be able to know the world around him.

In special disciplines there is no person, therefore they cannot fully develop a person. It can be fully developed only by those disciplines in which a person acts in a direct rather than indirect form. In special disciplines, a person is represented by a special subject, i.e. some part of himself and his soul. The consideration of the person in them is always mediated through this subject. In the humanities, a person is represented directly. Thanks to their participation, according to A.Kh. Bizhanov and A.N. Nysanbayev, that the spiritual and moral foundations of personal self-consciousness are formed. [14]. Therefore, they can, while developing universal creative abilities, at the same time contribute to the formation of it as a person. As a result, the educational space becomes, as noted by I. D. Frumin and B. D. Elkonin, the space of formation and development of the individual [15].

\section{Humanitarian disciplines in the process of forming the personality of a specialist}

It is no coincidence that not one major specialist is just a professional. He is also a culturally developed person. The deaf cannot be taught to admire music, a person must hear for this. Figuratively speaking, humanitarian disciplines learn to hear, and special ones learn to admire music. The blind cannot be taught to enjoy beauty, for this you must first learn to see. Humanities are taught to see in general, to distinguish beauty - special. Only a human hand can write, a monkey paw is not capable of this. In special disciplines they learn to write, the transformation of paws into a hand, the development of a human hand takes place in a cycle of humanitarian disciplines. There is another analogy: in the classroom, they teach to play one role, and in the humanities - in general acting.

All special disciplines make a specialist out of a person - a professional, and humanitarian - form him as a person, develop his own human qualities [16]. A developed person has a greater chance of becoming a good specialist than an undeveloped person. This was well said by F.M. Dostoevsky: «I, however, thought this because I always believed in the power of a humane, aesthetically expressed impression. Impressions gradually accumulate, break through the development of the heart cortex, penetrate into the heart, into the essence and form a person. Word - the word is a great thing! Well, all sorts of specialties will be grafted better to a man who is more humane. Of course, literature and all its impressions are far from constituting everything, but it contributes to the compilation of everything» [17, p. 191].

Based on vocational guidance, it is usually customary to divide people into humanities and non-humanities. But this division concerns only the profession. In a purely human sense, people are not divided into humanitarians and non-humanitiestechies. Humanities are absolutely all people just because they are people. What is connected with a person is of interest to absolutely all people, unlike what is associated with a narrow professional activity.

In the natural and technical sciences, man is least present, for they abstract from him. Therefore, their value to humans is only professional in nature. And fiction, poetry, music, and art in general, as a whole, relate entirely to man himself. Therefore, they are interesting to everyone.

Why are humanitarian disciplines called upon to form the personal qualities of a specialist? Because they are personal. They are primarily based on man and his personhood. If natural and technical disciplines determine the technology and methodology of professional activity, then humanitarian disciplines - the methodology and technology of transforming a 
person into a person, the formation of his personal qualities. They are called to consider not just a person, but how a person becomes a person or impersonality. But even in the second case, they also determine the methodology for the formation of precisely the individual. Revealing what impersonality is, they thereby highlight the personal qualities of a person. And moreover, in order to determine the impersonality of a person, one must first disclose what a person is.

If the natural and technical sciences, and the disciplines that represent them in the educational process, are built regardless of spirituality and morality, then humanitarian subjects should be built only on spirituality and moral values. Otherwise, they lose their essence. Well, since the basis of a person's personality is spirituality and morality, precisely humanitarian disciplines can contribute to the formation of the student's personal qualities.

Both the humanities and human personality are being built on the same foundation. Therefore, familiarization with the humanitarian culture is a necessary condition for the development of personal qualities of a future specialist. Spirituality and morality are the basis of all human life, especially - the basis of professional activity. Say, what is the use of society because a lawyer is an immoral person? The more spiritual and moral a person is, the more significant he is as a person, and professional qualities depend on his personal qualities. Why? For spirituality and morality, first determine person's attitude to himself, to others and to what he does.

It is impossible by any laws and rules of a person to force him to treat his business in good faith or to feel moral responsibility for his actions. This is determined by the level of his spiritual development and his conscience. And what can be more important and more significant in professional activity, as a conscientious attitude to your work and a sense of moral responsibility? Therefore, it is personality, which determines the professionalism of a person. Can a good person be a bad specialist? Not! For if he is a bad specialist, he will strive to become a good specialist. However, if he cannot become a good specialist, then he would rather not be a specialist at all than a bad specialist. The whole misfortune of modern civilization lies precisely in the fact that a person in it is considered only as a specialist and professional, but does not evaluate its personal qualities in any way, at a time when they are the main ones. After all, society is not a collection of abstract robots, but a joint being of real people who enter into appropriate relations between themselves. Therefore, a formal professional approach cannot be justified in any way.

The social life of people involves not only a form of relationship, but also an appropriate level of culture. Without culture, any community of people would be impossible, because it is the very foundation and backbone of society. Say, many formal positive transformations in society often do not produce results only because society does not have an appropriate level of cultural development. The entire historical process of human development consists of the interaction of two of its sides: social and cultural. The social side expresses the form of people's life together, and the cultural side expresses its content. Economics is not only industrial relations, but also an appropriate economic culture. Politics is not only political relations, but also political culture. Moreover, this is the case literally in all areas of social life. The same applies to any professional field.

Each specialist is characterized by two factors - professional and cultural. If we discard the cultural, then he will not be a full-fledged specialist. This has been reckoned with in the past. Now - mostly ignored. Therefore, any professional training should be conducted on the basis of humanitarian, i.e. human culture itself. When culture and the humanitarian foundation are ignored, its place will inevitably replace technocratism with its highly 
departmental approach, in which everything serves some separate areas, but not to the person. And then these areas begin to defeat man. Man is defeated by economics, politics, etc. And it turns out that the man himself serves everything - economics, politics, law and other things, but they do not serve man.

In particular, these technocratic models, ideas and approaches are opposed by various humanistic pedagogical and philosophical-educational directions that develop the main and specific patterns of development of the humanistic approach to the problems of institutionalization of education, upbringing and formation of value orientations. Supporters of various pedagogical and philosophical establishments share humanism itself, as a principle of education and upbringing systems. The concept of education and upbringing, referred to in the modern philosophy of education and pedagogy as «new humanism», unites representatives of philosophy, pedagogy, management, ethics, linguistic analysis, psychologists of the school of J. Piaget and his modern followers, a number of sociologists, and other. Representatives of «new humanism» (P. Hurst, J. Wilson, R. Peters, M. Warnock, L. Kolberg, A. Harris, and others) link the process of education with the value orientation of people [18].

Among the pedagogical-humanistic concepts, the existential-dialogic philosophy of education, developed primarily by O. F. Bollnow [19] (modern "optimistic», "positive existentialism»), stands out, which sees the meaning and prerequisites of pedagogical relations in interpersonal relationships, in the relationship between Me and You. Bollnow gives existentialism a new form, combining it with pedagogical issues. In his book «Existential philosophy and pedagogy», O. F. Bollnow presents pedagogy as an applied philosophical discipline, which focuses on the problem of educating a person who is open to the world in unstable forms of life.

He showed the importance of understanding the diversity of interpersonal emotionally colored moods and relationships that allow the teacher to realize the incomprehensibility of existence and form a careful attitude to the spiritual world of the pupil, setting an understanding of its depth and richness.

Bolnov creates the concept of «functional education», according to which any information and any impact, subject environment or socio-cultural environment contain an educational function. Only by communicating with spiritually rich adults, the child becomes a person, that is, a person. Education is the process of introducing the pupil into the system of value coordinates. The world is diverse, but it is the educator, who helps the student to place semantic, axiological accents, helping to form humanistic value orientations by introducing him to this diversity.

O. F. Bollnow called existential pedagogy the pedagogy of «impermanent forms», since pedagogical situations and the pupil himself are impermanent and changeable over time, and therefore it is not possible to technologize the process of education, to develop its algorithm once and for all. Pedagogical interaction is initially and forever unique, as well as the pupil is unique and inimitable. The core of Bollnow's existentialist pedagogical goal setting is His concept of moral education. Priority in education, according to him, belongs to self-education. The task of pedagogy, according to the Patient - is the development of such moral qualities of a person as «resistance to external influences» and, consequently, resistance to «mass character».

In this situation, many scientists who study social processes sound the alarm about the crisis in public life. Technocratism today concerns not only technical fields, but also the whole of social life. Technocratism opposes and destroys culture. Therefore, humanity 
faces a choice: either technocratism or culture. The technocratic path is the one - leading humanity to the abyss, the path that is disastrous. Therefore, many humanists, concerned about the problem of the future, say that if there is a culture of the 21st century, it will be entirely humanitarian. There is no other alternative. The other simply cannot take place. And one of the ways to overcome technocratism in public life is to strengthen the humanitarian foundation of higher education. "Technogenic civilization is now entering a period of special type of progress, when humanistic guidelines become the starting point in determining the strategies of scientific search» [20, p. 636].

\section{Freedom as a principle of humanitarian approach}

Everyone is a free sovereign being. His will, as Kant said, is autonomous. In other words, a person's will and actions are determined not by external causes - whether it be a natural necessity or even divine will - but by that exclusively internal law that he sets himself, recognizing him as the highest. Therefore, each person is an end in itself. He is a self-worthy being. Therefore, it cannot be treated as a means. «In everything created, anything and for anything can be used only as a means; only man, and with him every rational being is a goal in itself» [21, p. 414] - said I. Kant. This directly relates to the educational process.

In pedagogical theory, there was a deeply perverse idea that there is a subject of the educational process and is its object. However, if a person is lowered to the level of the object, then thereby depriving him of his freedom of will and autonomy. And how can he become a subject as a result of training, if in the educational process he was forged as an object? Therefore, in any learning process, it is necessary to reckon with the freedom and autonomy of the learner's will. Moreover, not only to be considered, but also to respect and assume it, regardless of whether it manifests itself directly or not.

In any student, in any student, a personality must be assumed. In reality, it turns out that if the student's personality begins to appear, then teachers and teachers first suppress it, and then the educational process and the student himself. As a result, a more personal student begins to feel flawed, and a mediocre student, unlike him, becomes more comfortable. But it should be the other way around. Discomfort should be felt by impersonality, by a student with a set thinking. And the student's personality should certainly be encouraged. And this is a completely normal and natural state of affairs. Moreover, such conditions are favorable for the mediocre. For they will feel their true inferiority and they will have a good example to follow. After all, there is nothing worse than the complacency of mediocrity. In any educational process, one must proceed from the fact that there are only its subjects, and no one acts as an object, let alone a means. There is a subject of teaching - this is a teacher, and there is a subject assimilating knowledge - a student. Education does not imply subjectobject relationships, but intersubjective relationships. Otherwise, interpersonal relations in the educational process turn into a relationship between a person and a thing.

If in the framework of natural and technical disciplines a student acts as an object of mastering knowledge, then in the field of humanitarian disciplines it cannot be such as such. Provided, of course, if humanitarian disciplines are not perverted and do not turn into a kind of ideology or natural disciplines. No natural or technical discipline takes into account that the student is a person. Moreover, the current state of the natural and technical sciences is such that even the personality of the scientist himself is not significant in them. Therefore, the teacher cannot show his personality in them. But since the humanities are personal, then when they are studied, they are not so much taught, i.e. they don't give instructions on what to do, they do not contain edifications, but how much they are presented with how 
other people acted, say, in history, or as they thought, for example, in philosophy. Thus, humanitarian disciplines come from the student's free will to accept or not to accept this or that material, as well as from his potential personality.

The primary learning tool in the humanities is an example. At the same time, the student retains absolute freedom of will and choice: if you want - imitate, and if you want to - not or if you want - choose what suits you best. Or: someone thinks so, and you think what you want. After all, the human mind, even the most ingenious, is so limited that it can develop only within the framework offered to it by existing ideas.

Human consciousness develops through the development and selection of ideas. Well, the more is choice, the greater is the choice. Many people in stories with brilliant mental abilities developed completely erroneous ideas only because they did not know and did not understand other ideas. The goal of humanitarian disciplines is only to acquaint and develop an understanding of ideas, not to force them to accept one or another, but to create opportunities for choice. After all, one way or another, a person still chooses himself, according to his inner feeling.

By providing many ideas, humanitarian disciplines provide an opportunity to choose a more adequate and truer idea. If the content of natural and especially technical disciplines is more likely to be like a military charter, and the justification of actions based on them is akin to an order, then in humanitarian fields this is fundamentally impossible. In the field of the natural and technical sciences, one should not think and act as one wants, but as one should. Humanitarian disciplines are human in the literal sense, for they are built on human freedom.

It is precisely because the principle of freedom lies at the basis of the humanities that they can achieve larger and more significant goals in shaping the student's personality. It is not without reason that in pedagogy there is a provision that the word only teaches, but educates an example. In humanitarian disciplines, not edification prevails, but an example. However, he is the most effective tool for the student's personal self-development. Therefore, we can say that while the educational function is the main one for the majors, the educational function is for the humanities. There is an opinion among students and teachers that humanitarian disciplines in the education system exist for general development, but have no practical use. Therefore, majority of people are outraged by the fact that they teach humanitarian subjects in technical or other special universities. Say, why should a future mathematician, programmer or other narrow specialist culture studies, philosophy, etc. However, the practical benefit of humanitarian discipline is primarily the formation of the person himself, the personality of the student - a future specialist. The practical use of majors is the training of a specialist. It is obvious that the practical benefit of the latter is based on the practical benefit of the former.

Discussion

Thus, humanitarian disciplines in higher education institutions fulfill three extremely important functions: first, they provide the basis for a holistic perception of knowledge and their deep understanding; secondly, they develop the student's creative abilities; thirdly, develop his personal qualities. Without creative and personal characteristics, not a single person, despite being prepared in the professional field, can be a full-fledged specialist. They form the basis of the professional qualities of any specialist. Only on their basis a 
person becomes a professional. Otherwise, he becomes one-sided and one-dimensional, as a result of which his purely professional skills become flawed. And in this regard, the value of humanitarian disciplines is more significant than even professional training. This shows their immediate practical benefit.

\section{Conclusion}

Today, humanity is concerned about the problem of its existence and survival. Too many problems have accumulated. People see their reasons in everything, in anything, but not in themselves. At the same time, forgetting that they themselves are the basis of everything. People can solve their problems only by changing themselves and, above all, by humanizing all spheres of their activity, revealing and realizing in themselves the full potential of a truly human and spiritual one.

\section{REFERENCES}

1. Ivanov O., Ivanova S. Formation of the Modern Educational Space: a Multidisciplinary View. Russian Journal of Philosophical Sciences, 2016, no. 1, pp. 39-49. (In Russ.)

2. Hunt M. History of Psychology / Translation from English. A.V. Alexandrova. Moscow, AST Publ., 2009

3. Lotman, Yu.M. «Education of the soul». Publishing House: St. Petersburg: Art-St. Petersburg, 2005. 624 p. (In Russ.)

4. Markhinin V.V. The origins of the relationship between the social sciences and humanities with philosophy and art in antiquity. Questions of Philosophy, 2018, no. 7. (In Russ.)

5. Kulikova T.V. The philosophy of education as a philosophy of understanding. Higher education in Russia, 2009, no. 11, pp. 144-150. (In Russ.)

6. Lektorskij V.A. Philosophy as an understanding and transformation. Questions of Philosophy, 2009, no. 1, pp. 17-24. (In Russ.)

7. Pashkova N.V. Understanding as a way of forming the space of personal being. (based on the material of philosophy of M.K. Mamardashvili). Abstract of Diss. PhD Philosoph. Sci., South Federal University. Rostov-on-Don. 2017. (In Russ.)

8. Sidorova U.V. Understanding as a hermeneutic phenomenon in the philosophy of H.G. Gadamer. Bulletin of the South Ural State University. Series: Humanities, 2009, no. 9 (142), pp. 136-140. (In Russ.)

9. Sinitsina L.N. The problem of understanding in the system of modern education. Competency Approach. Scientific and pedagogical journal of eastern Siberia. Magister Dixit, 2012, no. 4, pp. 176-185. (In Russ.)

10. Soloviev V.S. Criticism of abstract principles. Works in 2 volumes. Moscow, 1988, vol. 1.

11. Kuzmenko G. N. The problem of relevance of the ancient heritage in the socio-humanitarian knowledge (in terms of pedagogy). Perspektivy nauki i obrazovania - Perspectives of Science and Education, 2019, vol. 39 (3), pp. 10-19. doi: 10.32744/pse.2019.3.1 (In Russ., abstr. in Engl.)

12. Culturology. XX century. Anthology. Moscow, 1994.

13. The pedagogical theory of John Dewey [Electronic resource] // Sidorov S.V. The site of the research teacher. Available at: http://si-sv.com/publ/16-1-0-288 (accessed 2 February 2020).

14. Bizhanov A.Kh, Nysanbaev A.N. Spiritual and moral foundations of personal identity. Questions of philosophy, 2018, no. 7. (In Russ.)

15. Frumin I.D., Elkonin B.D. Educational space as a space of development ("school of growing up"). Questions of psychology, 1993, no. 3. (In Russ.)

16. Peoples J., Bailey G. Humanity: An Introduction to Cultural Anthropology. 11th Edition. Cengage Learning; 2017. $480 \mathrm{p}$.

17. Dostoevsky F.M. Complete Works in 30 Volumes. V. 13. Moscow, 1972.

18. Zinchenko V.V. The model of "new humanism" in the value system and principles of the modern social philosophy of education. Perspektivy nauki i obrazovania - Perspectives of Science and Education, 2014, no. 1, pp. 9-13. (in Russ.)

19. Starnikova C. G. Philosophy of education abroad: the experience of formation. Omsk Scientific Herald. Philosophical sciences, 2008, no. 5 (72), pp. 93-96. (in Russ.)

20. Stepin V.S. Theoretical knowledge. Moscow, Progress-tradition, 2003. (in Russ.)

21. Kant I. Works in 6 volumes. Moscow, 1963-1966. Vol. 4, part 1. (In Russ.) 
Информация об авторе

Меликов Ибрагим Мустафаевич

(Россия, Москва)

Профессор, доктор философских наук, профессор кафедры философии

Российский государственный социальный университет

E-mail: immelikov@gmail.com

ORCID ID: 0000-0003-2092-5134
Information about the author

Ibragim M. Melikov

(Russia, Moscow)

Professor,

Doctor of Philosophical Science,

Professor of the Department of Philosophy

Russian State Social University

E-mail: immelikov@gmail.com

ORCID ID: 0000-0003-2092-5134 